\title{
The impact of the recession on retail sales volumes
}

\section{SUMMARY}

This is the second of two articles on retailing activity in the current economic downturn. This article considers how the changing structure of the economy over the last decade has impacted on retail sales volumes. It compares the pattern of retail sales in the current recession to that observed in the recession of the 1990s. Notably, it examines why non-food stores appear to have (so far) performed better than food stores in the current recession.

It concludes that the observed growth in retail sales has been supported by falling retail prices and a flexible labour market that has limited the effect of unemployment on household consumption. It also identifies two factors that explain why non-food stores have performed more strongly than food stores in the recession: the changing structure of UK store types and relative price changes.
T he Retail Sales Index (RSI) measures an element of consumer spending, which is used in compiling the National Accounts. The RSI is also one of the most timely short-term measures of economic activity and it is an important input to the evidence base used in macroeconomic management. The monthly Retail Sales Statistical Bulletin produced by the Office for National Statistics (ONS) provides estimates of the volume of sales (after the estimated effects of prices have been removed) and value of sales (total value of sales in current prices).

This is the second of two ONS articles on retailing activity in the economic downturn. The first article (Anagboso, 2009) focused on recent changes in the value of retail sales from 2006 to 2008. This article will examine volume estimates for retail sales with a focus on the last two recorded economic recessions. The article will be organised as follows:

- the RSI in context

- long-term view of the RSI against the backdrop of the UK economy

- consideration of why some retail sectors have (so far) performed better in the current recession compared to the recession of the 1990s

- conclusion

\section{The RSI in context}

The ONS Retail Sales Inquiry is the most comprehensive measure of retail activity in Great Britain. It measures movements in the average weekly sales of retailers in
Great Britain. The RSI covers the activities of businesses selling goods directly to consumers and is a comprehensive broadbased sample survey which requests turnover information from approximately 5,000 businesses each month. The scope of the survey includes retailing businesses ranging from small corner shops to larger employers. Businesses provide turnover data, for example, the cash value of items passed through the till for a given reporting period.

The RSI uses annual chain-linking methods to calculate volume estimates. Chain-linking is a statistical technique which is the most appropriate way to measure sales volume growth, because it reflects changes in purchasing when consumers switch purchases to goods that have fallen in price. Annual chain-linking uses base year prices updated each year and then linked together to form a continuous time series. This linking process effectively absorbs price changes into the RSI volume index but in a way that maintains the integrity of the index as a measure of volume change. It allows price changes to be reflected in the measurement of retail sales volumes in a rapidly changing economy (McLaren 2009).

The RSI is published in three main categories: predominantly food stores, predominantly non-food stores and nonstore retailing and repair. Box 1 shows a breakdown of the RSI main categories.

Retailing is a high turn-over industry but it does not represent a large share of Gross Value Added (GVA) or roughly, Gross 


\section{Box 1}

\section{RSI main categories}

Publication category

- Non-specialised stores with food, beverages or tobacco predominating eg supermarkets

- Specialist food stores

- Retail sales of alcoholic drinks, other beverages and tobacco

Predominantly non-food stores

- Non-specialised stores where sales of food, beverages and tobacco is not predominant eg department stores

- Textile, clothing and footwear stores

- Household goods stores eg furniture, electrical appliances and hardware stores

- Other non-food stores

Table 1

\section{Household final expenditure by retail and non-retail expenditure}

\begin{tabular}{lrrrr} 
& & \multicolumn{3}{c}{ Chained volumes (reference year 2005) } \\
\hline Total household final consumption expenditure & 2005 & 2006 & 2007 & 2008 \\
RSI expenditure & $\mathrm{f784} \mathrm{bn}$ & $\mathrm{f796 \textrm {bn }}$ & $\mathrm{f} 815 \mathrm{bn}$ & $\mathrm{f} 823 \mathrm{bn}$ \\
Non-RSI expenditure & $33.6 \%$ & $34.1 \%$ & $33.9 \%$ & $34.0 \%$ \\
\hline
\end{tabular}

Source: ONS Retail Sales and Consumer Trends

Domestic Product (GDP). In 2008, total turnover in retailing was over $£ 280$ billion. However, despite a very high level of sales, retail sales contribution to GVA is much less than this. This is because the value added measure requires that intermediate costs (that is, goods and services used up in the process of producing output) are deducted from the total output. The value added measure of RSI (calculated as part of GVA) could therefore be seen as a measure of mark-up in the retail sector. In 2008, the value added measure of retailing (from National Accounts) was estimated to be over $£ 77$ billion or approximately 5.6 per cent of total GVA. In 2008, retailing mark-ups (the value added measure of RSI) were approximately 27 per cent of total retail turnover. Note that this measure is not a direct measure of profit margins as the value added measure includes the retail sector's own labour and capital costs. The Retail Sales Inquiry is not specifically designed to measure profit margins.

\section{Retail sales volumes and household} consumption expenditure

The monthly estimate of retail sales is a useful early indicator of consumer spending because it is available as early as three to four weeks after each reporting period. However, the RSI is not a full measure of consumer expenditure as only approximately a third of all consumer expenditure is spent in retail establishments. Table 1 shows a break- down of household expenditure by retail and non-retail expenditure.

The RSI excludes a number of goods - notably expenditure on motor cars, electricity, gas and other fuels. It also excludes services (for example, hotels and restaurants, banking, and air travel) which make up about half of total household consumption expenditure.

\section{Long-term view of the RSI against the backdrop of the economy}

Over the last 20 years, the UK economy has experienced two economic recessions - the current recession, which started in the third quarter of 2008, and another, which lasted from the fourth quarter of 1990 to the third quarter of 1991. Figure 1 shows GDP and total retail sales volumes (by contributions to its annual volume growth) over the last two decades. It shows that, apart from 2008, predominantly food stores (food stores hereafter) have generally shown a steady contribution to the growth in retail sales volumes. Over the 20 -year period, predominantly non-food stores (non-food stores hereafter) have been the main driver of retail sales volume growth, while nonstore retailing and repair have contributed the least to the growth of retail sales volumes (although in recent years, some aspects such as internet sales have contributed to the increase in contribution of this sector).

In the last decade, economic conditions have supported growth in the volume of retail sales; an annual average growth of 4.1 per cent between 1999 and 2008, compared to 1.6 per cent between 1989 and 1998. Sustained GDP growth, coupled with low unemployment boosted real average earnings, which grew at an average annual rate of about 4.0 per cent between 1999 and 2008 (see Table 2). Interest rates and general inflation were also significantly lower than the levels seen in the previous decade.

\section{Why have some retail sectors (so far) performed better in the current recession compared to the recession of the early 1990s?}

The pattern of retail sales in the current recession has differed considerably from what was observed in the 1991 recession. For instance, while there was a sharp contraction in non-food store sales in 1991, this category has continued to record positive growth in the current recession. The following section takes a closer look at both recessions.

\section{Retail sales in the 1991 recession} In the fourth quarter of 1990, the UK economy entered a recession, ten years after the last recession in 1980. The Gulf war that started in August 1990 triggered a spike in oil prices peaking at almost $\$ 40$ per barrel by October 1990. This oil shock was accompanied by a sharp rise in inflation (in September 1990 RPI inflation reached 10.9 per cent, its highest level in almost a decade) and acceleration in wage growth. Additionally, households faced record levels of unemployment, which added to the pressure on disposable incomes. Subsequently, there was a sharp contraction in the volume of retail sales. However, despite this, the value measure of total retail sales showed positive growth in that 


\section{Figure 1 \\ GDP and total retail sales volumes by the contributions to growth of its main components}

Percentage change on previous year, seasonally adjusted, chained-volume measure $(2005=100)$

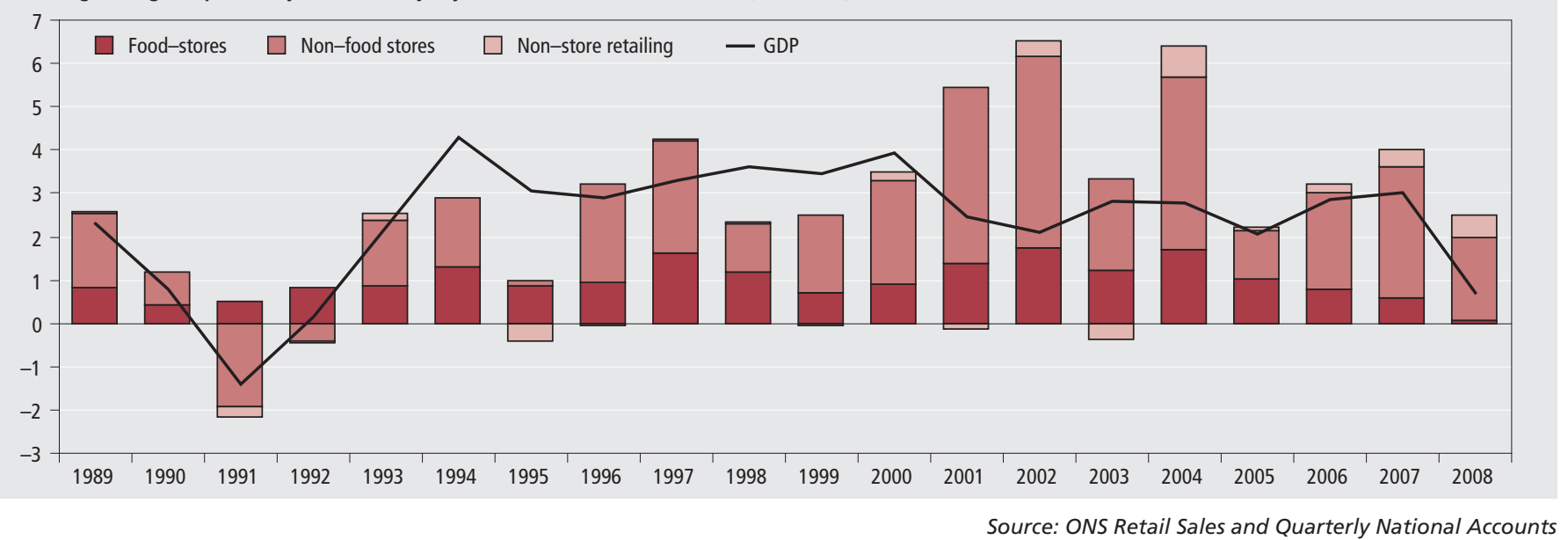

Table 2

\section{Two decades compared}

\begin{tabular}{|c|c|c|c|c|c|c|c|c|}
\hline \multirow[b]{3}{*}{ Time } & \multirow[b]{3}{*}{ GDP } & \multirow[b]{3}{*}{$\begin{array}{r}\text { Retail sales } \\
\text { Volumes }\end{array}$} & \multirow[b]{3}{*}{$\begin{array}{l}\text { Consumer } \\
\text { expenditure }\end{array}$} & \multirow[b]{3}{*}{$\begin{array}{l}\text { Unemploy- } \\
\text { ment rate }\end{array}$} & \multicolumn{4}{|c|}{ Annual average growth rates ${ }^{1}$} \\
\hline & & & & & & Net & Inflat & \\
\hline & & & & & $\begin{array}{l}\text { Average } \\
\text { earnings }\end{array}$ & $\begin{array}{l}\text { lending to } \\
\text { households }\end{array}$ & CPI & RPI \\
\hline 1989-1998 & 2.1 & 1.6 & 2.1 & 8.3 & $4.6^{2}$ & 8.2 & 3.5 & 3.9 \\
\hline $1999-2008$ & 2.5 & 4.1 & 2.9 & 5.3 & 4.0 & 10.4 & 1.8 & 2.9 \\
\hline
\end{tabular}

\section{Notes:}

1 These have been calculated as compound annual growth rates. The exception to this are unemployment rates which have been estimated as arithmetic means.

2 Average earnings data is available only from 1990 so the mean growth shown in the first row is based on the period 1990 to 1998.

3 Note that the CPI has only existed since 1996 so CPI rates of change before 1997 are constructed.

\section{Figure 2}

\section{Total retail sales by: volume, value and implied deflator}

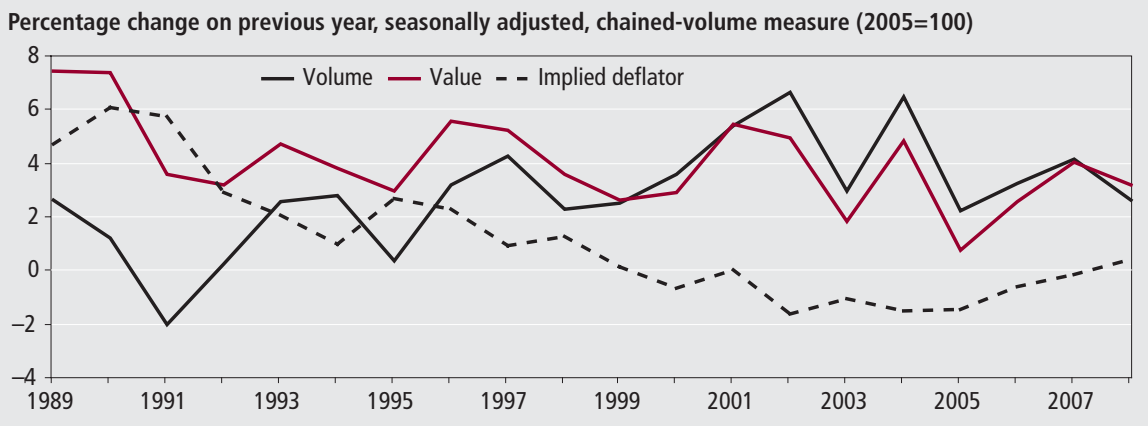

Note:

Source: ONS Retail Sales

1 The implied deflator is not seasonally adjusted, and prior to 2000, is based on the RPI rather than the CPI.

period; reflecting prevailing high retail prices

(Figure 2). Box 2 provides a description of how prices are estimated in the retail sector.

Disaggregated data shows that the sharp fall in the volume of retail sales in the early 1990 s was mostly driven by a fall in non-food store sales and non-store retailing; while food store sales recorded positive growth. Within non-food stores, all categories recorded negative growth for most of the recession. However, nonspecialised stores (for example, department stores) showed the least fall in sales output, even recording positive growth in some months (see Figure 3).

In the RSI, non-specialised stores are described as stores that do not specialise in the sale of food or other commodities. Examples of stores found in this category are department stores, discount stores where food items are not the predominant retail good (for instance shops that sell a wide variety of discount products), and family run shops that sell a range of household products (for instance ethnic food, and household essentials like batteries, shampoo, among others). As a broad spectrum of shops is included in this category, it is difficult to explain the resilience of this sector in the early 1990s.

To summarise, as the economy went into recession in the early 1990s, sales volume data has suggested that households cut back on discretionary expenditure and maintained non-discretionary expenditure. Consequently, food stores continued to record positive growth in volumes terms while there was a sharp fall in the volume of non-food store sales.

Retail sales in the current recession The current recession is the first recession in the UK for nearly 20 years and as the Bank of England has noted: 'the structure of our economy has changed significantly since the early 1990s' (see Dale 2009). The pattern of retail sales in the current recession is different from what was observed in the recession of the 1990s. In the last recession, there was a sharp contraction in the volume of sales in nonfood stores and non-store retailers, while food store sales recorded positive growth. In the current recession, food stores have, on average, shown a much weaker level of sales than observed in the 1991 recession. In addition, non-food stores and nonstore retailers have shown positive growth in retail sales in the first months of the current recession, a contrast to what was observed in the previous recession. Figure 4 shows the total volume of retail sales between 2006 and 2009, highlighting the contributions to growth in each month. It shows that so far, for the most part of the current recession, the total volume of retail sales has continued to show positive (albeit 


\section{Figure 3}

Total volume of retail sales in non-food stores by contributions to growth of its main components (1989-1992)

Percentage change on same month a year earlier, seasonally adjusted, chained-volume measure

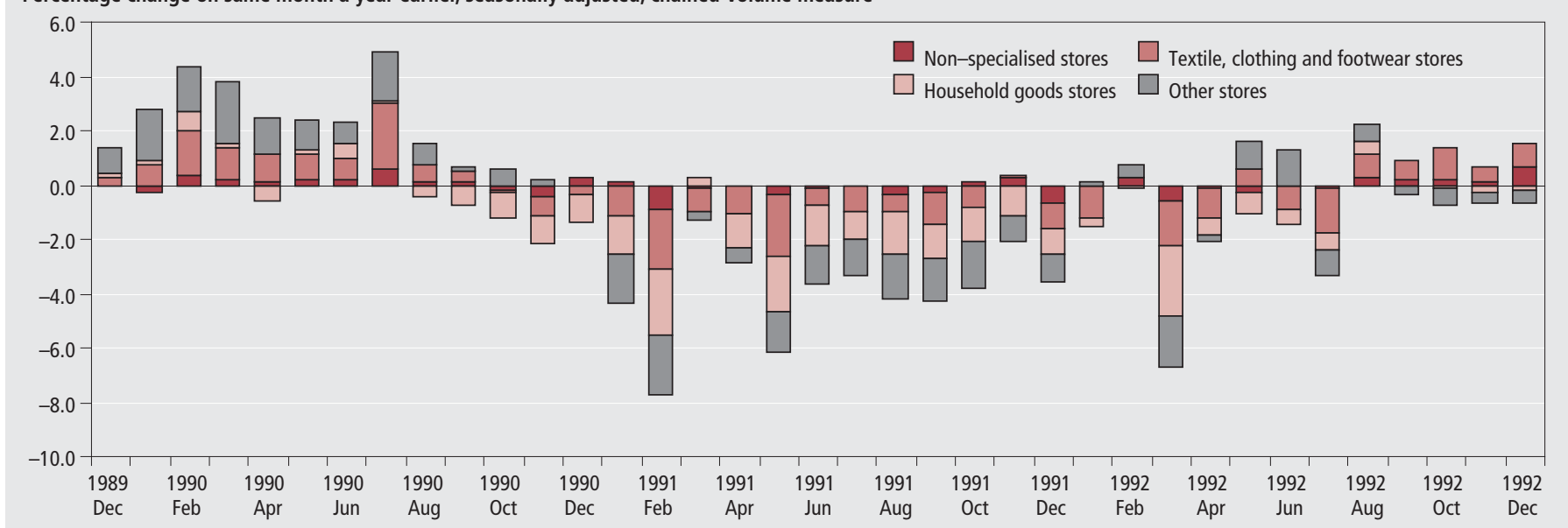

Source: ONS Retail Sales

\section{Figure 4}

Total volume of retail sales by contributions to growth of its main components (2006-2009)

Percentage change on same month a year earlier, seasonally adjusted, chained-volume measure (2005=100)

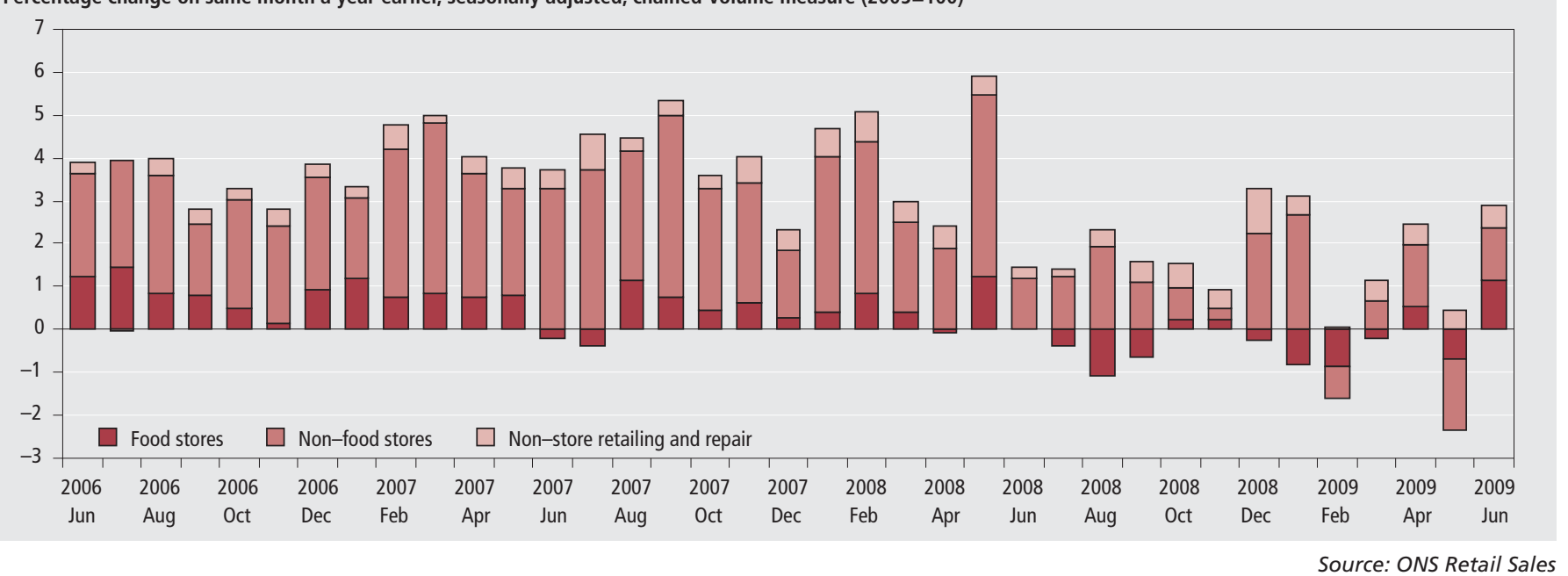

slower) growth, which has mostly been driven by the non-food retailing sector.

Other notable trends observed since the third quarter of 2008 are:

- food stores have contributed negatively to the growth of total retail sales volumes in eight out of 12 months of the recession

- the contribution of non-store retailing and repair to the total volume of retail sales has become increasing important. Even though this sector contributes approximately $5.3 \%$ to the total retail estimate, this illustrates to some extent, the impact of sales made over the internet. A separate experimental statistic is also available in the Retail Sales Statistical Bulletin

- the 12-monthly growth in the total volume of retail sales has recorded negative year on year growth only twice in the current recession: in February and May 2009. On both occasions, there was a strong contraction in the growth of non-food store sales. However, caution should be used in the interpretation of these two movements as the corresponding estimates in 2008 were unusually high resulting in an unusually low year-on-year movement.

Prevailing economic conditions explain why the volume of retail sales has shown positive growth for most of the current recession. These will be discussed under two separate headings: labour market conditions and price movements.

\section{Labour market conditions}

Labour market conditions are important in understanding consumer spending behaviour because the demand and supply of labour affect household earnings. In most months of the current recession, real average earnings based on the Labour Force Survey have recorded positive growth (albeit at a decreasing rate). The exception to this is January and February 2009 when real average earnings (including bonuses) recorded negative growth as the knock-on effect of the financial crisis took its toll on the economy. As earnings make up approximately 60 per cent of household income, a positive growth rate has supported household retail expenditure. Furthermore, households have benefited from lower debt servicing costs with the fall in interest rates over the last 12 months. Although households have faced reduced earnings, this has been slightly offset by lower tax payments and greater social transfers (benefits payments) which could support consumer expenditure. Simmons (1981) has shown that such redundancy payments and tax rebates provide a 


\section{Box 2}

\section{Measuring retail prices}

The Consumer Price Index (CPI) and the Retail Price Index (RPI) are the two main measures of inflation in the UK. These are comprehensive measures designed to cover a much wider range of transactions than just sales by retailers.

On the other hand implied price deflators (IPD), are derived by dividing the value series for the RSI by the volume series and are an alternative measure of price changes in the retail sector. A range of IPDs are published for different categories of the RSI.
The scope of the RSI is, by definition, 'limited to businesses that sell goods directly to the public, but may also include non-identifiable sales from businesses to non-households which have been excluded from the CPI' (McCrae et al 2008). Consequently there are significant scope, timing coverage and definitional differences between the CPI, RPI and IPD. Before 1997 the CPI is a constructed series. cushioning effect on spending which can last for at least six months.

The flexibility of the UK labour market could also be said to contribute to the household behaviour in the recession. Dynarksi and Sheffrin (1987) have demonstrated that workers who experience short spells of unemployment will often exhibit small changes in consumption. Thus, as people are moving quickly out of unemployment they are only making small changes in their consumption expenditure. The ONS Labour Force Survey shows that, so far, the largest proportion of unemployed workers (approximately 60 per cent) have been unemployed for less than six months. While this does not suggest that re-employment rates are high, it indicates that over the last year this may have acted to subdue the effects of unemployment on consumption. These factors partly explain why households have been able to maintain retail expenditure despite pressures from rising unemployment and reduced earnings growth.

\section{Price movements}

The resilience demonstrated by the retail sector in the recession can be partly explained by price flexibility over the past year.

Using data from the RSI, there is a clear split between price changes in the retail store categories. Figure 5 shows that over the years, food stores, have recorded a faster growth in prices compared to nonfood stores. The divergence between these categories is more apparent from 2007 onwards when food stores have continued to record rising prices while non-food stores have recorded a sharp fall in prices. It seems probably that this differential behaviour has contributed to the stronger growth in nonfood store sales.

Figure 5 shows that the 1990s were marked by positive price growth which started high and subsequently grew at a decreasing rate for the rest of the decade. The last decade has been noted as a period of negative price growth across most categories of the retail sector (apart from food retailing that has continued to record positive price growth). There are several factors that have supported falling prices in the retail sector. Some notable ones include: productivity gains, the relative strength of sterling and the integration of emerging countries into the global economy. Particularly, the 'China effect' has often been described as the strongest influence supporting low retail prices in the last decade. By shifting production to countries with low production costs, manufacturers have been able to produce goods at lower prices; thereby supporting low prices in the UK.

Falling prices have been particularly observed in household manufactured goods sold in non-food stores. For instance, within non-food stores, electrical appliance stores and textile, clothing and footwear stores have shown a sharp fall in prices over the last decade (Figure 6).

In the recession of the 1990s, households faced rising prices in all categories of the retail sector. In the current recession, this has not been the case. All categories of the RSI have recorded falling prices, apart from food which has shown increasing prices. For instance, among the four broad categories that make up non-food stores, textile, clothing and footwear stores have shown the fastest fall in retail prices (Figure 7). Indeed, this category has been the largest contributor to the positive growth in retail sales volumes since 2008 . The widespread price-reductions in this sector have contributed to positive growth of retail sales volumes being maintained, despite a weaker economic climate.

\section{Figure 5}

\section{Implied Price Deflators for retail sales}

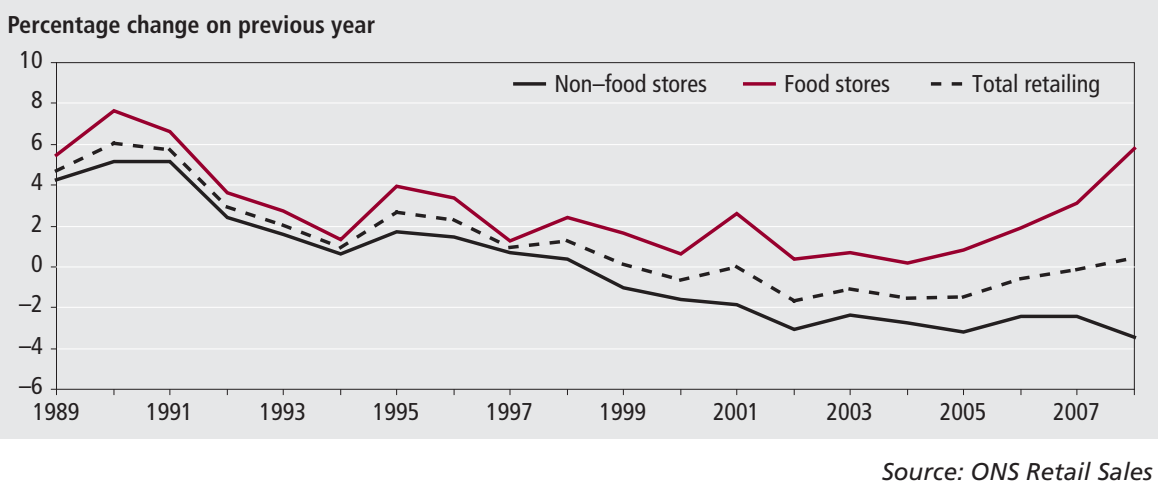

\section{Figure 6}

\section{The Consumer Price Index and Implied Price Deflators for selected non-food stores}

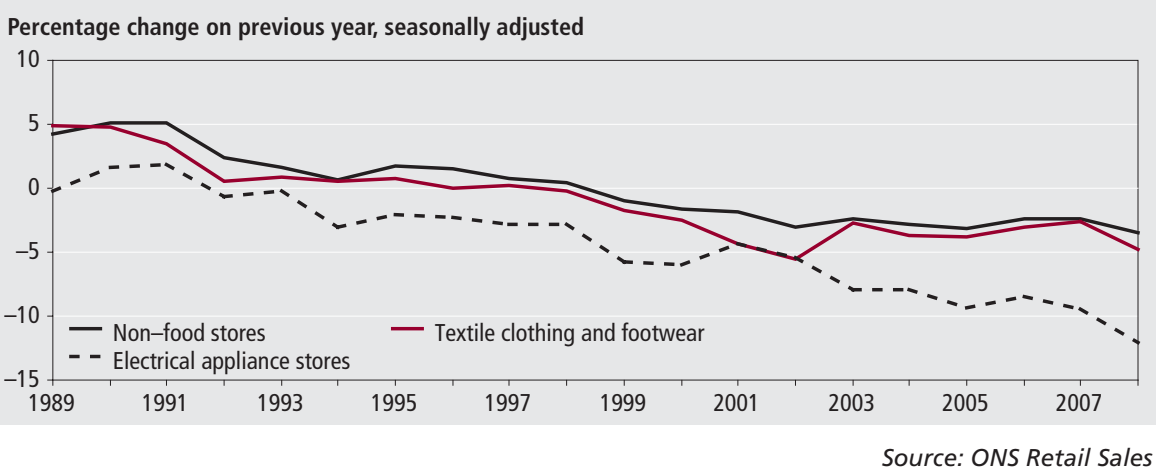




\section{Figure 7}

\section{Implied Price Deflator for retail sales in non-food stores (2006-2009)}

Percentage change on same month a year earlier

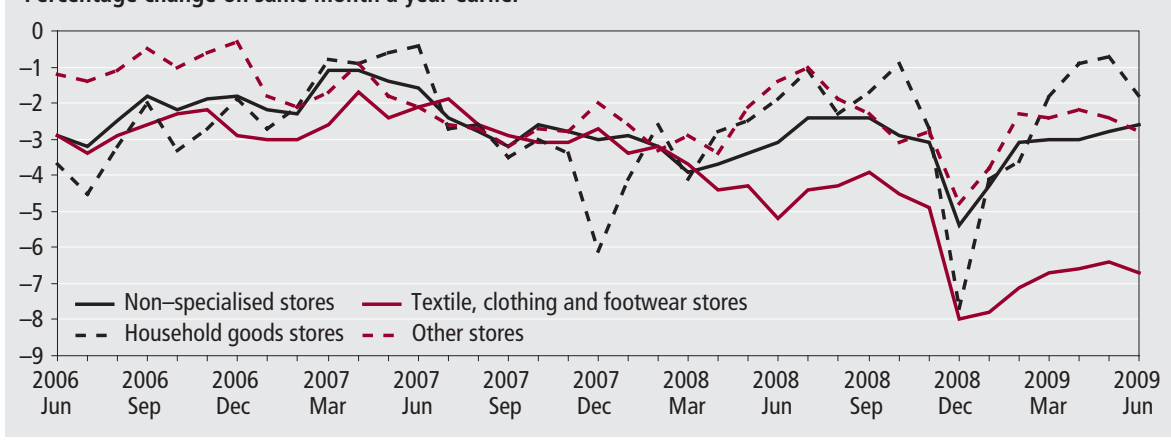

Source: ONS Retail Sales

The non-store retailing category has recorded negative price growth in every year since 1999. Non-store retailers sell a wide array of commodities so it is difficult to generalise on consumer behaviour on a commodity basis. Nevertheless, the categories that make up this sector have something in common; retailers have little or no geographical boundaries that separate them from millions of potential buyers. In this 'virtual' retailing environment, consumers are better able to truly shop around and so retailers have to offer competitive prices to attract consumers. In addition, dedicated online retailers can be said to face relatively lower fixed costs of production which can (at least in theory) be passed on to consumers.

\section{Why do some non-food stores appear to be (so far) doing better than food-stores in the current recession?}

Over the last 12 months (from June 2008 to June 2009), the 12-monthly growth rate of RSI volumes has mostly been driven by a growth in non-food store sales. Indeed the positive growth in retail sales so far in this recession has been almost entirely driven by sales in textile, clothing and footwear (within this category, clothing stores make up about 85 per cent of the aggregate) and 'other' non-food stores.

This is a reversal of what was observed in the recession of the 1990s when food-stores continued to show positive growth despite the overall contraction of economic activity. At least two factors can be identified that bear on this: the changing structure of store types in Great Britain and relative price changes.

Changing structure of GB store types Data from the Retail Sales Inquiry suggests that the composition of goods sold in food stores has changed over time. Table 3

continued to record positive growth in the recession.

Over the years, the changing structure of UK store types means a growing number of 'predominantly food' stores also sell an increasing proportion of non-food items; blurring the distinction between store types and making it more difficult to see a clear split between discretionary and non-discretionary expenditure in the RSI. The RSI shows that food store sales have generally been weaker than non-food store sales. Because of the changing structure of UK store types, the underlying weakness in food stores cannot necessarily be attributed to a fall in discretionary expenditure.

summarises the composition of goods sold in a selection of predominantly food stores over time. It shows that in the ten-year period from 1998 to 2008 , there has been an increase in the proportion of non-food items sold in food stores.

In a recession, households typically cut down expenditure on discretionary items because of labour market uncertainties. Thus, as unemployment increases, there may be a fall in discretionary expenditure. For instance, non-food store sales might be more cyclical because they sell goods whose purchase can often be deferred. So far, only certain categories of non-food stores (notably household goods stores and non-specialised stores) have exhibited such cyclicality. Other store categories such as textile, clothing and footwear stores have

\section{Table 3}

\section{Commodity breakdown of retail sales in a selection ${ }^{1}$ of food stores}

\begin{tabular}{lrrrrrr} 
& & & \multicolumn{2}{c}{ Percentages as proportion of total turnover } \\
\hline Year & Food & $\begin{array}{r}\text { Clothing and } \\
\text { Footwear }\end{array}$ & $\begin{array}{r}\text { Household } \\
\text { goods }\end{array}$ & $\begin{array}{r}\text { Alcohol, } \\
\text { Other goods }\end{array}$ & $\begin{array}{r}\text { confectionery, } \\
\text { tobacco }\end{array}$ & Total \\
\hline 1998 & 70.4 & 3.6 & 3.4 & 9.4 & 13.1 & 100 \\
2008 & 58.3 & 5.2 & 8.5 & 14.4 & 13.8 & 100 \\
\hline
\end{tabular}

Note: Source: ONS Retail Sales Inquiry

1 Note that proportions are based on a selection of retail businesses.

\section{Figure 8}

Implied deflator for retail sales in food and non-food stores

Percentage change on same month a year earlier, chained-volume measure

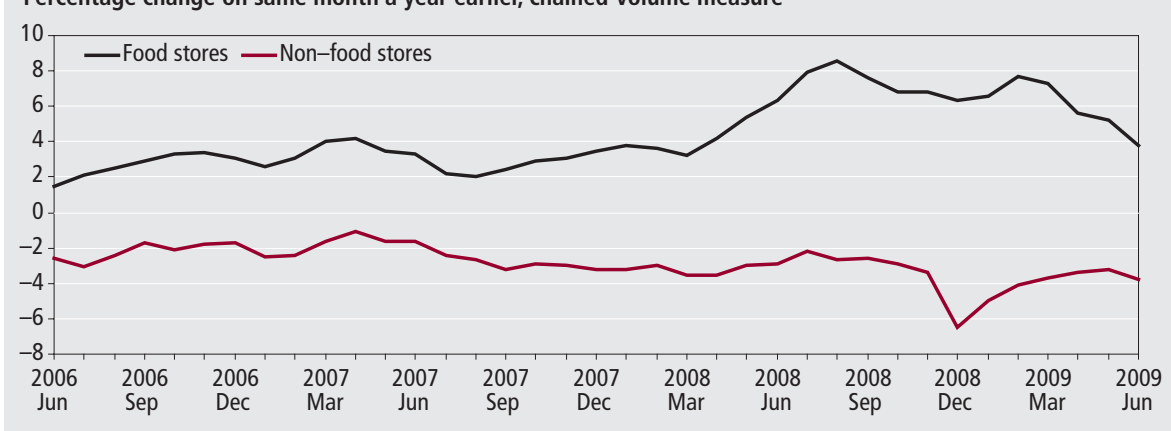

Source: ONS Retail Sales 


\section{Figure 9 \\ Volume of retail trade in Euro Area ${ }^{1}$}

Percentage change, month on same month a year earlier, working days and seasonally adjusted volume measure

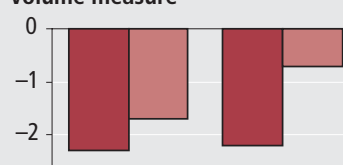

$-3$

$-4$

$-5$

$-6$

\begin{tabular}{cc}
\hline Food, drinks \& tobacco \\
\hline 2008 & 2008 \\
Nov & Dec
\end{tabular}
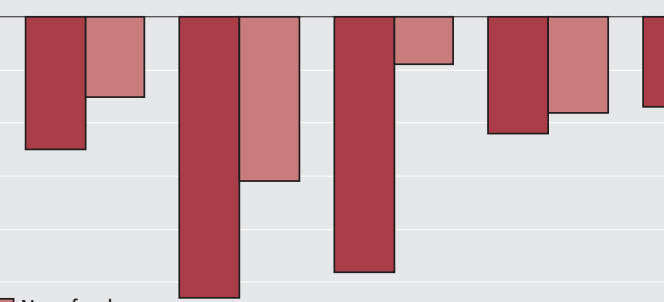

$\square$ Non-food

$2009 \quad 2009$

Feb

2009

2009

2009
Apr 2009 May

Note:

1 The euro area includes Belgium, Germany, Trela Malta, the Netherlands, Austria, Portugal, Slovenia, Finland and Slovakia.

\section{Conclusions}

So far, retail sales volumes have recorded positive growth in most months of the current recession, despite other economic indicators showing weakness in the UK economy. The observed growth in the volume of retail sales has been supported by falling retail prices and a flexible labour market which has subdued the effect of unemployment on the household consumption of retail items.

Since the onset of the recession, the performance of non-food stores has been relatively stronger than food stores, a reversal of what was observed in the previous recession. The two main contributing factors to this are the changing structure of UK store types and relative price changes. A blurring of the distinction between retail store types makes it more difficult to see a clear spilt between discretionary and non-discretionary expenditure in the RSI. Because of this, the underlying weakness in the volume of sales in food stores cannot necessarily be attributed to a fall in discretionary expenditure.
Retail sales in non-food stores have been supported by price-cutting which is particularly noticeable in household manufactured goods such as electrical appliance stores and, textile, clothing and footwear stores.

\section{Notes}

1. For further discussion on the differences between the RSI and household final expenditure, see Dolling et al (2005)

2. The 'China effect' is often described as the deflationary effect on the price level in the UK and other countries that has come from China's huge export-led growth.

\section{ACKNOWLEDGEMENTS}

The authors would like to acknowledge input by Mathew Powell, Khalid Khan and Valerie Fender. In particular, Richard McCrae's invaluable support in providing most of the data is noted. Of course, any omissions or errors remain the sole responsibility of the authors.

\section{CONTACT}

(《)elmr@ons.gsi.gov.uk

\section{REFERENCES}

Anagboso M (2009) 'Retail sales in the downturn - Understanding patterns and trends', Economic \& Labour Market Review $3(\mathrm{x})$, pp $17-23$ and at www. statistics.gov.uk/cci/article. asp? $\mathrm{id}=2146$ Dale S (2009) 'Tough times, unconventional measures', Remarks at the Association of British Insurers Economics and Research Conference, London, 27 March 2009

Dolling M, Herbert R and Skipper H (2005) 'Early estimates of Consumer Spending' at www.statistics.gov.uk/cci/article. asp? ID =103 $6 \&$ Pos $=2 \&$ ColRank $=1 \&$ Rank $=1$

Dynarski M, and Sheffrin S (1987)

'Consumption and Unemployment' The Quarterly Journal of Economics 102(2), pp. 411-428.

McCrae R, McLaren C H, Wood J and Youll R (2008) 'Decomposing the Retail Sales Index implied price deflator and the CPI', Economic \& Labour Market Review 2(5), pp 35 -39 and at www.statistics.gov.uk/CCl/article. asp? ID =1997

McLaren C H (2009) 'Changes to the Retail Sales methodology, Economic and Labour Market Review, Volume 3, No. 6, June, Office for National Statistics. Available at www.statistics.gov.uk/elmr/06_09/ downloads/ELMR_Jun09_McLaren.pdf

Simmons G (1981) 'The effect of the recession on the retail trade', International Journal or Retail and Distribution 9(3), pp 10-16. 